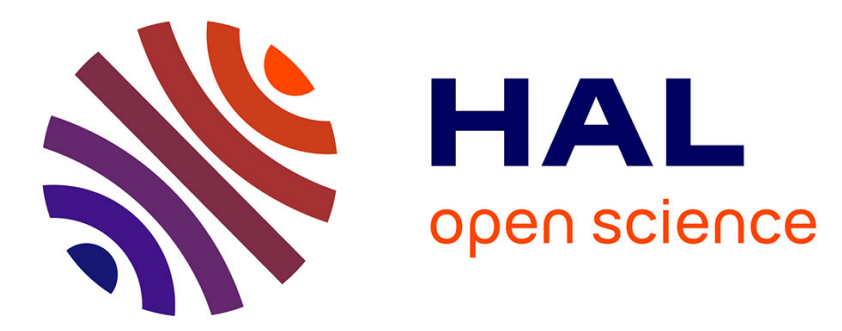

\title{
An Experimental Study on Flow of Micronized Silicon Carbide Particles Through Sintered Porous Materials
} Aswin Chinnaraj, Eddy El Tabach, Khaled Chetehouna, Nicolas Gascoin

\section{To cite this version:}

Aswin Chinnaraj, Eddy El Tabach, Khaled Chetehouna, Nicolas Gascoin. An Experimental Study on Flow of Micronized Silicon Carbide Particles Through Sintered Porous Materials. Lecture Notes in Mechanical Engineering, 2017, Innovative Design and Development Practices in Aerospace and Automotive Engineering, pp.95-101. 10.1007/978-981-10-1771-1_15 . hal-01570493

\section{HAL Id: hal-01570493 \\ https://hal.science/hal-01570493}

Submitted on 12 Aug 2017

HAL is a multi-disciplinary open access archive for the deposit and dissemination of scientific research documents, whether they are published or not. The documents may come from teaching and research institutions in France or abroad, or from public or private research centers.
L'archive ouverte pluridisciplinaire HAL, est destinée au dépôt et à la diffusion de documents scientifiques de niveau recherche, publiés ou non, émanant des établissements d'enseignement et de recherche français ou étrangers, des laboratoires publics ou privés. 


\title{
An experimental study on flow of micronized Silicon Carbide particles through sintered porous materials
}

\author{
Aswin CHINNARAJ ${ }^{1, *}$, Eddy EL-TABACH ${ }^{2}$, Khaled CHETEHOUNA ${ }^{1}$, \\ Nicolas GASCOIN ${ }^{1}$ \\ ${ }^{1}$ INSA Centre Val de Loire, PRISME laboratory, University of Orleans, 88 Boulevard \\ Lahitolle, 18000 Bourges, France \\ ${ }^{2}$ PRISME laboratory, University of Orleans, 63 avenue de Lattre de Tassigny, 18020 \\ Bourges, France
}

\begin{abstract}
Transport of suspended particles in porous media occurs in numerous processes of civil engineering and aerospace engineering. Literature survey indicating the mechanism of movement of suspended particles through porous media and the subsequent damage in engineering environment are not sufficiently known. This paper deals with a new concept of a laboratory test bench which permits to better understand the mechanism of particle intrusion into porous media. The results of the laboratory studies on the flow of suspended particles (Silicon Carbide) through sintered porous material (Stainless Steel) are discussed. The effects of flow rate and particle concentrations on the amount of damage (i.e., permeability impairment) and depth of penetration (from inlet towards outlet) are emphasized particularly.
\end{abstract}

Keywords: suspended particles, transport, sintered porous medium, microparticles

\section{Introduction}

The transport of suspended particles in porous media occurs in a variety of natural and industrial process such as propagation of coke, formed by fuel pyrolysis at high temperatures, through porous materials used in the combustion chamber of hypersonic vehicles [1-3]. Many attempts were made by different investigators to explain the mechanism of particles flow through porous media. Still the problem is far from being solved, there are some points of agreement among various investigators regarding the importance of various factors such as flow rate, particle size, etc., on these mechanisms. We can find many studies in the literature related to damage caused by particles suspended in fluid flows. Most of the literature on this subject is on natural porous material [4] or artificially created porous material [56].

\footnotetext{
${ }^{*}$ Corresponding author: Research engineer at INSA-Centre Val de Loire (Campus de Bourges), Bourges, France

E-mail address: aswin.chinnaraj@insa-cvl.fr
} 
Donaldson et al. [7] made significant contribution to the mechanism of the flow of particles through porous media using laboratory experiments and a statistical interpretation of the results. They conducted some experiments by passing suspended silica particles through three types of core plugs. The specific core plugs used in their experiments were taken from Berea, Noxie and Cleveland sandstone. Additional studies on the flow of suspended particles through porous media were performed by Davidson [8]. Davidson used alundum cores with a mean pore diameter of 90 microns, a permeability of Darcies and a porosity of $35 \%$. The suspended particle are made with silica powder having a particle size distribution characterized by a median size of 3 microns with a 12 microns upper bound. Gruesbeck and Collins [9] attempted to explain the abnormal decline in productivity of producing wells in terms of the movement of naturally occurring fine particles in porous media. They made a rather questionable hypothesis on the interrelationship of the flow velocity and the rate of entrainment. Muecke [10] presented an interesting qualitative analysis of fine particles movement through unconsolidated sand. The results are based essentially on a visual observation using a microscope. The work of Jordan et al. [11] dealt with an offshore sea-water injection project where the brine was filtered through 0.45 micron filters prior to injection.

According to the clean-bed filtration theory, the flow of suspended micro-particles through porous material can be characterized by two important phenomenon, the transport and the attachment. The transport is defined as the movement of the particles to the grain surface (porous material or the solid matrix) and is quantified by the single collector efficiency factor $\eta_{0}$. The deposition of the micro-particles on the porous material is defined as the attachment phenomenon. The attachment of the particles to the grain surface is quantified by the collision efficiency $\alpha$, which is either favourable $(\alpha=1)$ or unfavourable $(\alpha<1)$. In favourable conditions, the suspended micro-particles and the grain surface are differently charged and viceversa in unfavourable conditions. Both favourable and unfavourable conditions are the results of the collision of the dispersed particles with the grain surface. Under favourable conditions every collision results in an attachment. The amount of the particles collected in the porous material can be calculated or verified by the collector efficiency factor. In this condition the transport step plays an important role in the deposition of the particles on the grain surface; the smaller the particles are, larger the amount of transported particles due to enhanced diffusion of the particles in the fluid flow. Hence, in this condition, the size of the particles also plays an important role in the deposition. But the effects of particle size in the unfavourable conditions are difficult to understand, due to the various factors associated with them [6].

Apart from the above two phenomenon, aggregation is another important process which occurs when the suspended particles clump together forming clusters. This may results-in increase of size of the suspended particles, which, when encountered by the grain surface can block the fluid flow completely. These aggregates loss their kinetic independence while they retain the individual properties and are more likely to deposit on the solid matrix during the flow through porous material. 
The instability of the suspended particles results in the aggregation and it depends on the type of system (fluid and the suspended particles) involved. Further details can be found in [12-13]. Brownian motion of the micro-particles plays an important role in all the above phenomenon.

The literature survey indicates that the mechanism of particle intrusion into sintered porous materials is not known in sufficient way. In this paper, we present an experimental test bench in order to better understand the mechanism of particles intrusion into sintered porous materials. The obtained results, using this test bench, by studying the flow of Silicon Carbide micro powder into sintered porous material (Stainless Steel) are discussed.

\section{Experimental Setup}

The developed experimental setup consists of an Autoclave which is used to mix the water and the micronized powder. The autoclave consists of a motor and this is used to stir the mixture of water and the powder. This ensures the transport of the particles to the cell and also prevents the settling of the powder in the bottom of the autoclave. Nitrogen is used to pressurize the Autoclave at a constant pressure $\left(\mathrm{P}_{\text {in }}\right)$ and push the mixture of powder and water into the experimental cell. Due to safety reasons we used micronized Silicon Carbide $(\mathrm{SiC})$ for our experiments. The mass flow rate is measured from the Coriolis mass flowmeter (Brooks). The inlet pressure of the experimental cell is measured using a pressure transducer (Rosemont 3051S). The pressure difference between the inlet and outlet of the test cell is measured using a differential pressure transducer (Rosemont 3051S). Both the pressure transducers and the mass flowmeter are connected to the data acquisition card. This data acquisition card is connected to the Keithley multimeter and Excel is used to control the data acquisition through the Keithley multimeter. The acquired data are stored in the Excel for future exploitation. The data obtained can be used to calculate the change in permeability of the porous material with respect to time during the experiment. The porous material used here is fabricated by STEMM located in France. The overall porosity of this porous material is of about $30 \%$. The active diameter of the porous material is $16 \mathrm{~mm}$. The $\mathrm{SiC}$ powder used for this set of experiment has an average particle size of 35 microns. The micronized powder used in this study is relatively smaller than the pore diameter of the porous material.

The porous material used in these experiments is made up of Stainless Steel with individual spherical particles. This material has a thickness of $3 \mathrm{~mm}$ with a density of $7850 \mathrm{~kg} \cdot \mathrm{m}^{-3}$. The maximum pore diameter of the porous material used is $88 \mu \mathrm{m}$ and the average grain size of the material is $200 \mu \mathrm{m}$. The porous material was weighed before and after the experiment. The porous material is then dried in an oven for 30 minutes and again weighed. Several trails were conducted before choosing the duration of time for the drying process and it is found that there is no significant difference on the material weight above 15 mins of drying. The differ- 
ence in the weights of the porous material gives the amount of particles deposited on the porous material.

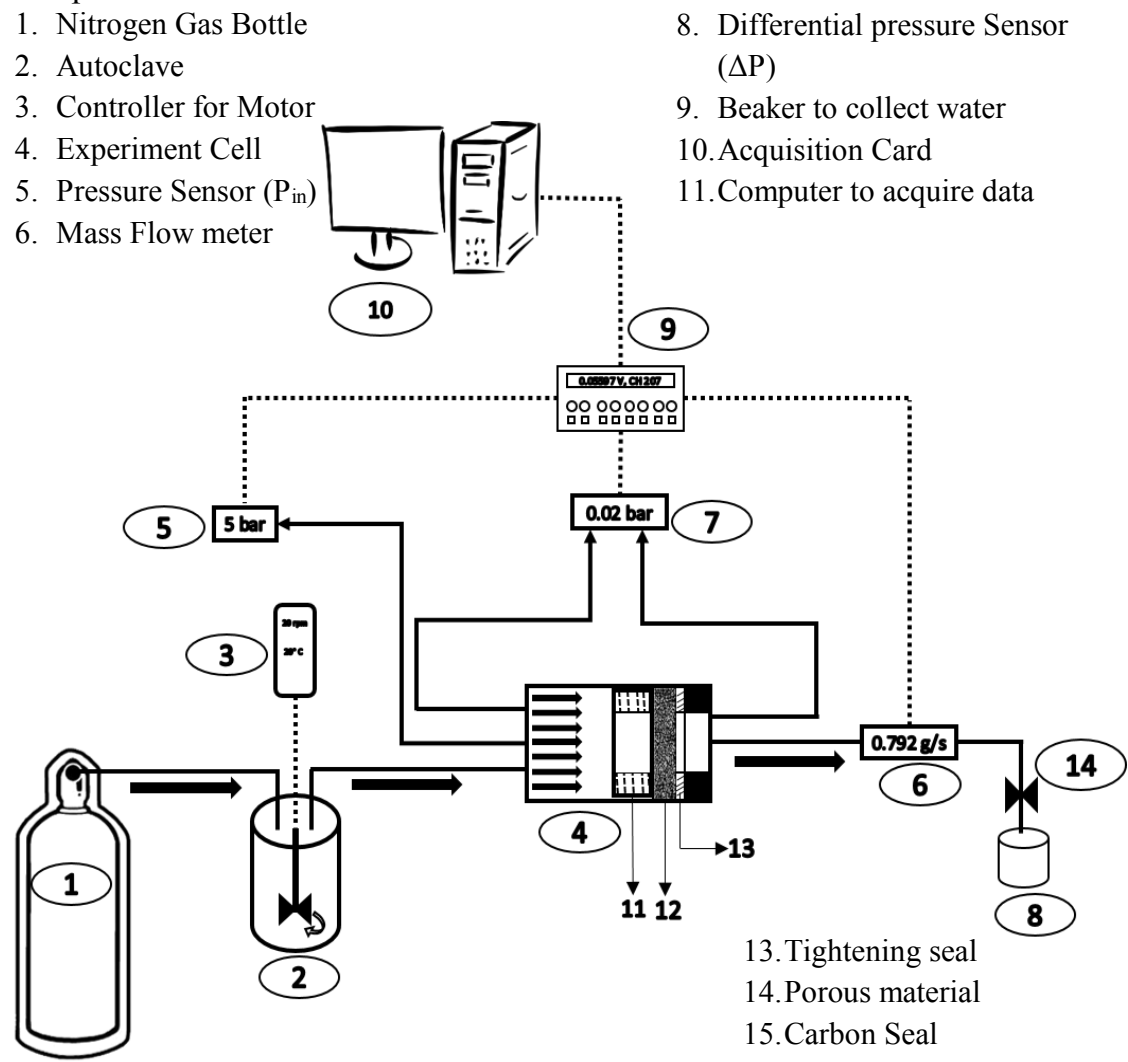

Fig 1. Experimental Setup.

\section{Results and Discussion}

The experiments were conducted using the above experimental setup on the sintered porous material (Stainless Steel). After each experiment the surface porous samples are needed to be wiped due to the deposition of the $\mathrm{SiC}$ particles on the surface which do not interest us to be studied. The figure 2 gives a brief idea about the unwiped and the wiped surface of the porous samples after the test. Usually the deposition on the surface is wiped after drying the porous sample in oven for 30 mins at $100^{\circ} \mathrm{C}$. It is found that, if the surface is wiped before the oven drying process, there are possibilities of few SiC particles resting on the porous surface due to wetness.

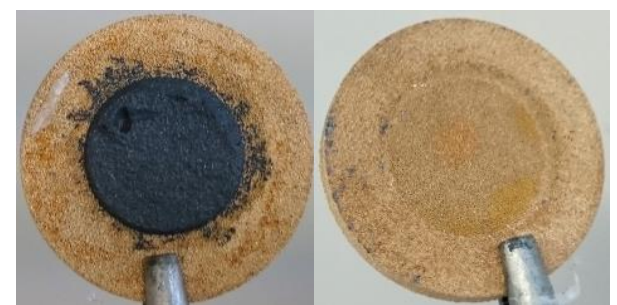

Fig 2. Porous sample before and after surface cleaning. 
Figure 3 gives the cumulated weight rise $\left(W_{c}\right)$ in the porous material after each interval of the tests, while figure 4 gives the results of weight increase (W) in the porous material (after cleaning the powder on the porous material surface) after each test for different $\mathrm{P}_{\text {in }}$ values. It can be noted that $W_{c}$ in the 5 bar tests is higher than that of 2 bar and 10 bar. This is explained by the fact that the pressure $\left(P_{i n}\right)$ of 2 bar is not sufficient for pushing enough particles inside the porous material. While, with a value of 5 bar for $P_{\text {in }}$ the particles enter the porous material. On the other hand, increasing $\mathrm{P}_{\text {in }}$ to 10 bar, certain amount of the particles flow through the porous material due to high pressure. The total weigh increase in the porous sample for different values of $P_{\text {in }}$ tests of 2, 5 and 10 bar of the pressure are 0.182 $\mathrm{g}, 0.1876 \mathrm{~g}$ and $0.1697 \mathrm{~g}$ respectively.

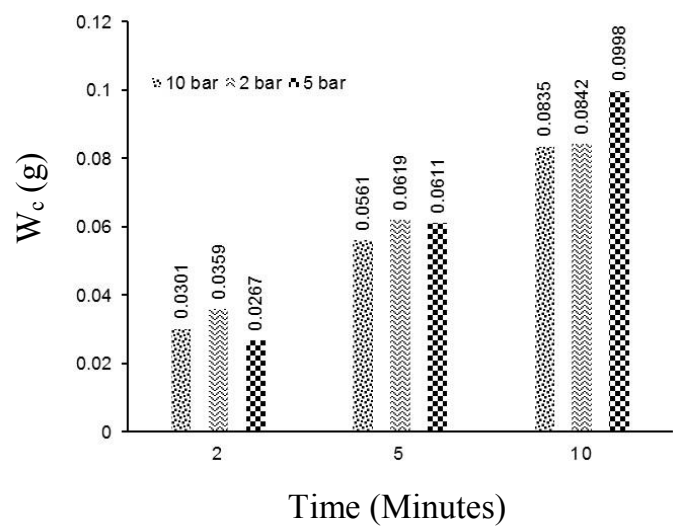

Fig 3. Cumulated increase in weight of the porous material after 3 durations.

It is important to note that for tests of $5 \mathrm{~min}$ and 10 mins there was no flow after certain period of time due to the total blockage of the porous sample inside the experimental cell. Hence for flow duration more than 2 mins the permeability of the porous sample becomes zero.

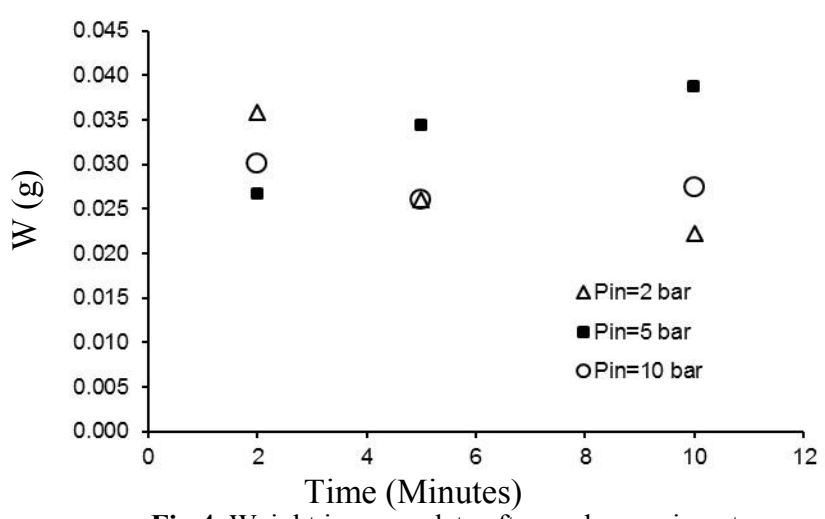

Fig 4. Weight increase data after each experiment. 


\section{Conclusion}

In this paper, the experimental test bench for studying the effects of infiltration of the micronized $\mathrm{SiC}$ particles was discussed and the results of the first few experiments were published. The increase in weight of the porous samples due to the deposition and infiltration of the $\mathrm{SiC}$ particles were studied and important results were found. It is found that the $\mathrm{SiC}$ particles with sizes thrice smaller than the average pore diameters of the porous materials block completely the porous samples for the tests of durations higher than 2 mins. During the future experiments, the investigation of the other $\mathrm{SiC}$ particles with higher particle sizes are to be accomplished and a numerical model is to be developed based on these results.

\section{References}

[1] Gascoin, N., Fau, G., Bioud, J., Gillard, P., Permeation of inert and supercritical reactive fluids through metallic and composite material, 40th AIAA/ASME/SAE/ASEE Joint Propulsion Conference \& Exhibit, 2010.

[2] Fau, G., Gascoin, N., Gillard, P., Bouchez, M., Steelent, J., Fuel pyrolysis through Porous Material: Coke Formation and Coupled effect on Permeability, J. Analytical and Applied Pyrolysis, 2010.

[3] Gascoin, N., High temperature and pressure reactive flow through porous material, International Journal of Multiphase flow 37 (2011), pp. 24-35.

[4] Tahar, I., Ahmed, B., Mohamed, K., Nasre-Dine, A., Particle transport within water saturated porous material: Effect of pore size on retention kinetics and size selection, C.R. Geoscience 345 (2013), pp. 392-400.

[5] Amir, Z., Brij, M., Flow of dispersed particles through porous material - Deep bed filtration, Journal of Petroleum Science and Engineering 69 (2009), pp. 71-88.

[6] Ryan, M., Yusong, L., The effect of particle size on the deposition of fluorescent nanoparticles in porous material: Direct observation using laser scanning cytometry, Colloids and Surfaces A: Physicochem, Eng. Aspects 418 (2013), pp. 84-91.

[7] Donaldson, E.C., Baker, B.A., Carroll, H.B., Particle transport in sandstones, SPE 6905, presented at the $52^{\text {nd }}$ Annual Fall Meeting of the SPE, October 9-12 (1977), Denver, Colorado.

[8] Davidson, D.H., Invasion and impairment of formations by particulates, SPE 8210, presented at the $54^{\text {th }}$ Annual Fall Meeting of the SPE, September 23-26 (1979), Las Vegas, Neveda.

[9] Gruesbeck, C. and Collins, R.E., Entrainment and deposition of fine particles in porous media, SPE 8430, presented at the $54^{\text {th }}$ Annual Fall Meeting of the SPE, September 23-26 (1979), Las Vegas, Neveda.

[10] Muecke, T.W., Formation fines and factors controlling their movement in porous media, Journal of petroleum technology, 1979, pp. 144-150.

[11] Jordan, C.A., The bay marchand pressure maintenance project-unique challenges of an offshore sea water injection system, Journal of petroleum technology, 1969, pp. 389-396.

[12] Elimelech, M., Gregory, J., Jia, X., Williams, R.A. (1998). Particle deposition and aggregation: measurement, modelling, and simulation. Colloid and Surface Engineering Series, Butterworth-Heinemann, Oxford.

[13] Hiemenz, P.C., Rajagopalan, R., (1997). Principles of Colloid and Surface Chemistry. Marcel Dekker Publishing Co.. New York. 